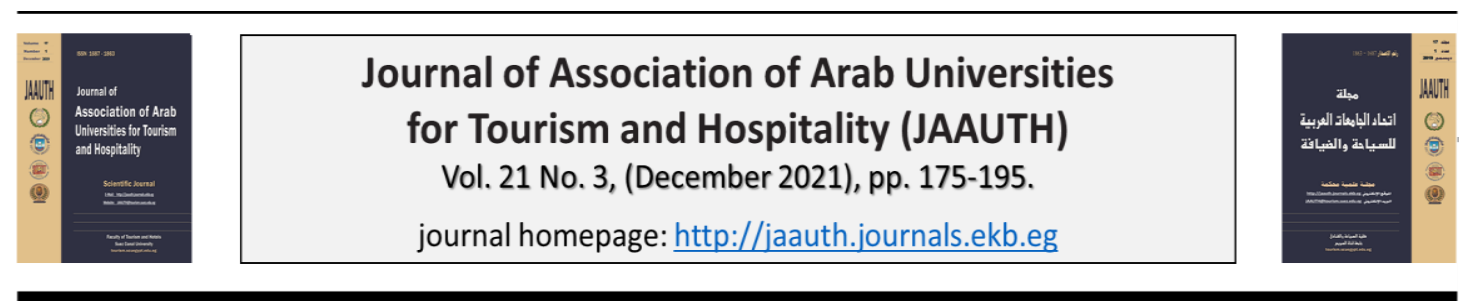

\title{
The Role of Heritage Hotels in Increasing Tourist Flow Rates in Cairo, Egypt
}

\author{
Hany Salah Sadek
}

Higher Institute for Specific Studies, Heliopolis

\section{ARTICLE INFO ABSTRACT}

Keywords:

Heritage Hotels;

Tourist Flow;

Hospitality Industry

\& Cairo City.

\section{(JÄUTH) \\ Vol. 21, No. 3, (December 2021), PP.175-195.}

The main argument of this paper is to examine the role of heritage hotels in improving Egyptian tourism revenues, as this type of hotels provides the attractiveness of Historical Cairo with a new dimension represented in a mixture of tangible and intangible elements such as natural, cultural, man-made resources, attractions, facilities and services. The field study was done through a survey to a sample of hotel guests in Cairo, where 372 online questionnaires were sent to the respondents, and 255 questionnaires were completed. The data was analyzed using the SPSS software - version 23. The most important results were that there is a positive correlation between heritage hotels and increasing tourist flow in Cairo, where this type of hotels attracts special types of tourists with high spending level. In addition, the need of establishing tourist paths within Historical Cairo to encourage the development of local crafts, and the need to develop creative marketing strategies that create "Local Brands" to communicate with global electronic platforms about heritage hotels.

\section{Introduction}

Heritage tourism has interest in both natural and man-made features such as cave exploration, nature reserves, gardens and marine parks, as well as exploring the built heritage within cities, community's unique local practices, culinary specialties and other local community intangibles such as storytelling, local games and dances, local mythology, etc. Heritage tourism also observes cultural events, festivals, performing arts and other forms of popular culture (Haynes, 2018). Egypt is a country with more than a 7000 years old civilization. It has long been known for being a top holiday and cultural-tourism destination since European explorers discovered the pyramids. The emergence of elegant hotels around the country in strategically located places was one of the many advantages of Egypt becoming the next big thing in tourism (Sameh, 2019). Heritage tourism is a new term for a special format of cultural tourism easily separable from history tourism, nature tourism, arts tourism, and other tourism types. It is the type of tourism which is oriented towards cultural heritage in both its tangible and intangible forms.

Historical hotels of Egypt played an important role in Egypt's history and it is very important to preserve these exquisite national treasures. In addition to reuse of 
historical buildings to create heritage hotels is a growing practice within the hospitality industry in Egypt to particularly respond to the demand created by urban heritage tourists, especially independent heritage tourists. Such advantages of the adaptive reuse of historical buildings as heritage hotels should encourage the local communities to develop more heritage hotels, despite the technical difficulties architects face to transform historical buildings into star-rated hotels. Heritage hotels might not be susceptible to the introduction of some space-thirsty amenities and services such as parking, a swimming pool, a health club, etc. while still be attractive to urban heritage tourists and responsible tourists who would sacrifice such missing amenities for the heritage hotel's charming character, convenient location and its positive impact on the local community and the environment (Chan, 2021).

Egypt has seen inbound arrivals plummet since the outbreak of COVID-19 with a decrease in tourism demand due to this pandemic. 2021 has seen an increase in inbound flows from new destinations such as India, China, Kazakhstan and Poland as well as a higher percentage of travelers from the Gulf region and North Africa (Euromonitor, 2021).

\subsection{Research Problem}

Previous studies have highlighted the impacts of heritage hotels on areas of urban heritage (DMG Consulting Services, 2015), they focused on the experiential marketing and sustainable culture of heritage hotels (Lee and Chhabra, 2015). In addition some studies cover topics related to enhancing organizational competitive advantage through service excellence (Abuya, 2014). The research questions can be formulated in the following forms:

a) Do heritage hotels represent a source of tourist attraction in Egypt?

b) Do heritage hotels contribute to improving tourism revenue in Egypt in particular?

c) Do heritage hotels have a role in increasing the number of tourists in a particular area?

\subsection{Research Objectives}

The research objectives include:

a) Clarify the role of heritage hotels in developing tourist flow rates in Egypt.

b) Identify the value that tourists have for heritage hotels in cultural areas.

c) Identify the importance of heritage hotels to the Egyptian hospitality and tourism market.

\subsection{Research Hypothesis}

The study designed to prove the following hypothesis:

There is a significant relationship between heritage hotels and increasing the number of tourists in Cairo, Egypt.

\section{Background}

\subsection{Tourists Flow Rates in Egypt}

The tourism industry including the hospitality activates, is one of the most affected industries by the COVID-19 crisis. Tourism destinations recorded a decline in the 
number of foreign tourists in 2020 by one billion tourists compared to 2019. The sharp decline in international travel led to a loss of about USD 1.3 trillion in export revenues, more than 11 times the loss during the last economic crisis in 2009. There are three steps that must be taken into account in order to build a better future for tourism in times of crisis (Pangestu, 2021):

- Improve traveler confidence;

- Understand and track new market trends and the drivers of demand;

- Commit to build more resilient tourism sectors, leveraging renewed interest in sustainability in the long term.

A positive rate of change in the number of tourists was achieved during January and February of 2020, compared to 2019. The number of tourist arrivals to Egypt until August 2020 is very low compared to 2019 as a result of precautionary measures. The change in the number of tourist arrivals to Egypt between 2019 and 2020 is shown in the following table:

Table 1

Change in the Number of Tourist Arrivals (Numbers in Thousand)

\begin{tabular}{|l|c|c|c|c|}
\hline \multirow{1}{*}{ Months } & $\begin{array}{c}\text { Prior to the } \\
\text { Crisis }\end{array}$ & $\begin{array}{c}\text { During to the } \\
\text { Crisis }\end{array}$ & $\begin{array}{c}\text { Rate of } \\
\text { Change }\end{array}$ & $\begin{array}{c}\text { Direction of } \\
\text { Change }\end{array}$ \\
\cline { 2 - 4 } & $\mathbf{2 0 1 9}$ & $\mathbf{2 0 2 0}$ & $\mathbf{( \% )}$ & $\uparrow$ \\
\hline January & 861 & 945 & 10 & $\uparrow$ \\
\hline February & 885 & 942 & 6 & $\downarrow$ \\
\hline March & 1097 & 398 & -64 & $\downarrow$ \\
\hline April & 1220 & 1 & -100 & $\downarrow$ \\
\hline May & 932 & 2 & -100 & $\downarrow$ \\
\hline June & 1083 & 4 & -100 & $\downarrow$ \\
\hline July & 1225 & 89 & -93 & $\downarrow$ \\
\hline August & 1221 & 223 & -82 & \\
\hline
\end{tabular}

Source: The Egyptian Center for Economic Studies, 2021.

Tourist flow rates in Egypt during the year 2020 witnessed exceptional circumstances due to the COVID-19 crisis, where flights were suspended on March 19, 2020. The Egyptian government took a number of measures to face the COVID-19 in the tourism sector, as follows (SIS, 2021):

- Hotels and resorts are required to get the Health Safety Certificate after fulfilling the regulations made by the Ministry of Tourism and Antiquities, approved by the cabinet in accordance with the standards of the World Health Organization (WHO).

- Travelers seeking accommodation in Egypt should be aware that hotels currently operate at $50 \%$ capacity with reinforced hygiene standards.

- Tourists in the country have to respect activity limitations designed to minimize contagion risk, and it is compulsory to wear a mask when out in public in Egypt.

The total number of tourists who visited Egypt in 2020 totaled three million and a half, with a total expenditure of $\$ 4.01$ billion, which is regarded as an unimpressive number considering the negative repercussions the COVID-19 pandemic. The 
following figure shows the total number of tourists and their spending rates in Egypt from 2010 to 2020 (CAPMS, 2021):

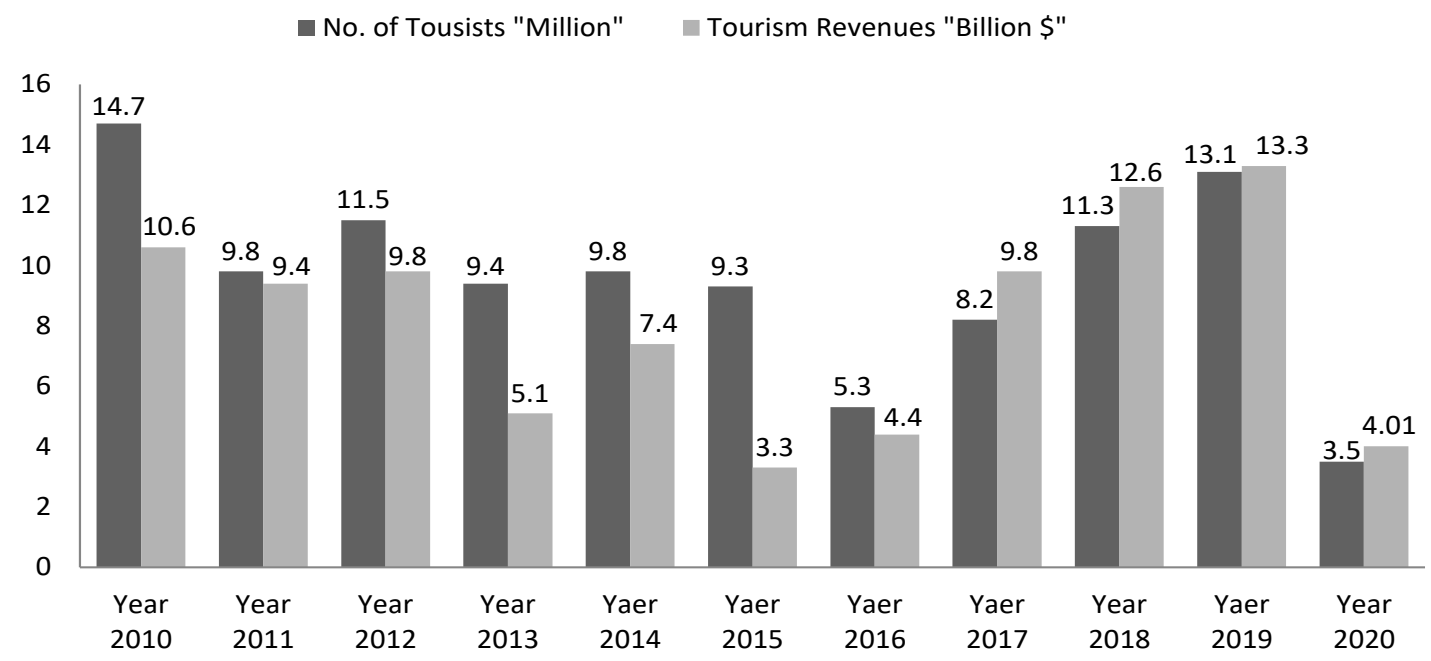

Fig.1.Total Number of Tourists \& Tourism Revenues from 2010 - 2020

Source: CAPMS, 2021

\subsection{Culture Tourism in Cairo}

Planning for Heritage Tourism would include identifying local or regional points of interest, developing and organizing those points of interest for visitation, and developing promotional and informational materials and guides for distribution to travelers and tourists through tourism bureaus, chambers of commerce, and by other marketing methods (adapted from Gibson, 2015). The National Trust for Historic Preservation (USA) defines heritage tourism as "traveling to experience the places, artifacts and activities that authentically represent the stories and people of the past and present". It includes visitation to cultural, historic, and natural resources (Jackson, 2020). Tourism destinations around the world are making efforts to both preserve and draw visitors to their cultural heritage sites, and the heritage tourists travel longer distances and spend more than other travelers (Stinson, 2010). Culture tourism to Egypt is the oldest type of tourism, however Historical Cairo is not attracting many tourists because they have to mingle with the local communities which was not preferable during the early decades after WWII. Egypt had for many years conducted ambitious cultural tourism promotion efforts at various levels: the level of multilateral organizations, bilateral cooperation channels and national tourism policies that include heritage as a key component. However, many of such promotion efforts were focused on ancient Egypt and the beaches with limited interest in Historical Cairo. Using the rhetoric of Gibson (2015), the case of cultural heritage in Cairo is that of plentiful tourism opportunities that should be capable of attracting tourists, while very few of them are developed as cultural heritage destinations ready for visitation. Consequently, very few of the possible cultural heritage attractions would have available promotional materials or guides for visitors making such unknown attractions difficult to consider for heritage tourism itineraries. A recent study of Historical Cairo showed that only 13 destinations were available for tourism 
itineraries, with only 5 of them having more than $90 \%$ of the visitors: the citadel, Khan el-Khalili, sultan Hassan masjid, and Ibn-Talon masjid. Considering that Historical Cairo has 603 monuments and triple that number in heritage buildings that are not registered as monuments, 5 visited destinations do not make a legible percentage of the potential cultural heritage opportunities. All the destinations took the form of physical architectural attractions that fulfill the criteria desirable by tour operators: places of controlled access, monitored interactions with the local community, and complete security surroundings. Cairo Citadel, Sultan Hassan masjid and Khan el-Khalily are high on the list for cultural tourism visits because of their controlled access and good monitoring. The free roaming visitors are not encouraged by the tour operators because of visitor insurance issues.

\subsection{Characteristics of Heritage Tourism}

Harris (2010) stated that heritage tourists most likely have the following characteristics:

- Well Educated: Most heritage tourists have advanced degrees. Education level is the single most significant factor that influences cultural and heritage participation and travel.

- Gender Impacted: Women typically plan family vacations and group trips, and also control more personal discretionary income, consequently families and groups that had women members are more likely to seek heritage tourism.

- Age Sensitive: Participation in cultural and heritage events peaks between ages 45 and 65, when people are at the height of their careers, earning power, and discretionary income.

- Generous Spenders: Visitors to historical and cultural sites spend about $\$ 62$ more per day than other types of visitors. They tend to spend money on antiques, art, gourmet food, wine, health food, and outdoor experiences such as biking, hiking, canoeing, and bird watching.

- Stay Longer: Visitors to heritage hotels stay longer than the average travelers and need a higher quality service.

- Interested in Authenticity: The heritage tourists seek out experiences that are authentic to learn about the visited community's history and culture.

According to Childs (2018), "Culture and heritage tourists often stay longer and spend a lot more money in general than other tourists do. In fact, one study showed that a culture and heritage tourist spent as much as $38 \%$ higher per day and they stayed $22 \%$ longer overall compared to other kinds of travelers". Childs research showed that the benefits of heritage tourism can be categorized into three groups, as follows:

- Economic Benefits: which include, inject new money into the economy, boosting businesses and tax revenues, create new jobs, support small businesses and enable them to expand, protect of important local resources, build vital relationships among and within local communities and help the development and maintenance of new community amenities. 
- Social Benefits: which contain, build social capital, promote preservation of local traditions, customs and culture, promotes positive behavior, improve the community's image and pride, promotes community beautification, build opportunities for healthy and useful community relationships and partnerships, create enjoyable opportunities for both local residents and visitors, boosts local investment in heritage resources and amenities that support tourism services.

- Environmental Benefits: which comprise, encourage a culture of preservation, boost awareness of the tourist site, and encourage local residents and visitors to be mindful about their impact on the natural and built environment.

\subsection{The Heritage Cycle in Cairo}

The "heritage cycle" as developed by Simon Thurley (2005), is a representation of the process by which a cultural heritage item becomes a "desired heritage destination". The process envisioned by Thurley (2005) starts by the cultural heritage item being understood, valued, cared for, in order that cultural heritage item to be enjoyed. The whole process is then repeated as enjoying the cultural heritage item calls for more understanding, more valuing, more care, more enjoyment and so on for many more cycles. Thurley's heritage cycle explains that a cultural heritage item that is not understood, valued and cared for, won't be enjoyed by visitors and cannot be added to any tourism itinerary. The 602 registered monuments in Historical Cairo (as indicated by URHC, 2020) would require first the step of "understanding" that spells out of the spheres of archeologists and urban heritage conservators and their epistemic communities; into the public spheres. After heritage items start to be "publicly" appreciated and valued; they might start to be cared for by individuals, community groups or governmental agencies. Caring for a cultural heritage item would mean -in architectural conservation terms- to at least "consolidate" the current situation before deciding to preserve, conserve, or even develop the site and plan an adaptive re-use of the item. Based on its architectural cultural and functional value, structural integrity, anticipated role in the future of the community functioning; such a cultural heritage item gets valued and becomes illegible for the "care" it needs as a visitors' destinations and a community's resource. Only after a cultural heritage item gets the understanding, valuing and care; its possible attractiveness to visitors" "enjoyment" might be evaluated by tour operators for consideration on their itineraries.

A cultural heritage property becomes attractive when the tour operators discover that it might be "enjoyed" by its visitors (as the last step of Thurley's heritage cycle) depending on tourism dynamism in the area and the local community's acceptance of outside visitors. In addition to the cultural heritage item's own attributes, the tour operators factor-in the area's safety record, insurance cost for the visitors, cost of promoting the site as a destination, etc. before deciding to include the site on their tour itineraries. The intensive efforts invested in each of the steps of the cultural heritage cycle by the community, tour operators, promoters, organizing bodies result in the cultural heritage item to be certified as a possible cultural heritage destination. Such invested efforts by the tour operators and the community representatives are necessary to tie the supply and demand sides of the culture tourism. Without the involvement of the tour operators, working on the supply side remains ineffective and 
incapable of attracting demand. Approaching Berlin International Travel Fair (ITB) and similar global events might be one of the possibilities, but inviting influential tourism operators, organizing local events that have global exposures and better yet creating a positive image of the locality for the global audience strengthens demand for local culture tourism.

\subsection{Heritage Hotels in Cairo}

Heritage hotels in Egypt do not make a significant portion of the hotel accommodation market, despite they are well perceived and have a good image and get favorable pricing. Heritage hotels offer the several advantages such as: unique accommodation character, strategic locations within the heritage areas, economic benefits to the local community and local investors, reduced construction cost and reduced carbon footprint for the hotel (Chan, 2021). There are few heritage hotels in Egypt that tourists like to stay in, such as (HHE, 2021):

- The Old Cataract, Aswan City: A grand hotel on the Nile, built in 1899, which has hosted leading dignitaries from Sir Winston Churchill to Princess Diana.

- The Winter Palace, Luxor City: A grand colonial style hotel built in 1886.

- The Palestine Hotel, Alexandria City: Boasts one of the most prominent locations on the Mediterranean. It was specially built and furnished within six months to host the Arab League Summit in the early 50s.

- Cecil Hotel, Alexandria City: A historical hotel where the author Somerset Maugham, Winston Churchill and even Al Capone, stayed.

There are many heritage hotels in Cairo, such as:

- Cairo Marriott Hotel is a large hotel located on the Nile, and just west of downtown Cairo, Egypt. The central section of the hotel was once the Gezirah Palace built for the Khedive Ismail Pasha in 1869. The palace and site were converted into a modern hotel by Marriott International by adding two towers of almost 540 guest rooms to the North and South of the palace.

- Mena House Cairo hotel is a luxurious hotel and resort located at the foot of the great pyramid of Cheops. In 1885, an English couple Ethel and Hugh Locke-King began construction of the hotel and opened it to the public in 1886 as The Mena House. The hotel was created using Islamic Architecture style with wooden window shutters, wooden balcony details, stone and wood interior details.

- Shepheard's Hotel was the leading hotel in Cairo and one of the most celebrated hotels. In 1860 the hotel was renamed Shepheard's Hotel, after its owner Samuel Shepheard became co-manager of the hotel with a Mr. Hill (who was Mohammed Ali Pasha's head coachman) in 1841.

- Nile Ritz-Carlton, Cairo, the iconic luxury hotel. The landmark property, which reopened under the stewardship of The Ritz-Carlton hotel management company. The hotel was founded in the middle of 1950 and was opened in 1959 as the first Hilton hotel on the shores of the Nile.

The following table shows a list of the most important heritage hotels in Egypt: 


\section{Table 2}

List of heritage hotels in Egypt

\begin{tabular}{|l|l|l|l|l|l|}
\hline \multicolumn{1}{|c|}{ Hotel Name } & \multicolumn{1}{|c|}{ City } & $\begin{array}{c}\text { Opening } \\
\text { Year }\end{array}$ & $\begin{array}{c}\text { Classif } \\
\text { ication }\end{array}$ & \multicolumn{1}{|c|}{ Owner } & $\begin{array}{c}\text { Management } \\
\text { Company }\end{array}$ \\
\hline The Old Cataract & Aswan & 1889 & $* * * * *$ & EGOTH & Accor \\
\hline The Winter Palace & Luxor & 1880 & $* * * * *$ & EGOTH & Accor \\
\hline The Palestine Hotel & Alexandria & 1964 & $* * * * *$ & EGOTH & Helnan \\
\hline The Cecil Hotel & Alexandria & 1929 & $* * * *$ & EGOTH & Steigenberger \\
\hline Marriott Hotel & Cairo & 1869 & $* * * * *$ & EGOTH & Marriott \\
\hline Marriott Mena House & Giza & 1869 & $* * * * *$ & EGOTH & JW Marriott \\
\hline Shepheard Hotel & Cairo & 1841 & $* * * * *$ & EGOTH & Helnan \\
\hline The Ritz Carlton & Cairo & 1959 & $* * * * *$ & Egypt Hotels & Ritz Carlton \\
\hline
\end{tabular}

Source: The Holding Company for Tourism and Hotels, 2021.

\subsection{The Economic Impact of Heritage Tourism}

The economic impact of heritage tourism can be analyzed from two sides (Brida et al., 2013):

- On the microeconomic level, the economic value of heritage tourism can be defined as a set of benefits for a particular community.

- On the macroeconomic level, the economic value of heritage tourism is reflected in the stimulation of other economic branches through direct, indirect, and induced effects which contributes to the overall development of a particular destination.

Heritage tourism has a direct economic impact on the local economy, these economic benefits involve (Kumar, 2017):

- Providing job opportunities for the local people.

- The high value of real estate in the tourist destination.

- Infrastructure development in the tourist attraction area.

- Increasing cultural communication between peoples, which leads to the development of the tourism industry and thus attracting large numbers of visitors, especially in various occasions such as festivals, conferences and other events.

This is in addition to the unique characteristics of heritage tourists, which are the high cultural level and high spending rates, as well as the long stay in heritage hotels.

The tourism sector, as one of the main pillars of the Egyptian economy, achieved revenues of $\$ 4.01$ billion in 2020 (compared to revenues of $\$ 13.3$ billion in 2019), and Egypt received about 3.5 million tourists. While the number of tourists in 2019 was about 13.1 million, and the number was expected to reach more than 14 million in 2020, until the COVID-19 epidemic began to spread, which led to a decline in tourist flow rates (Farag, 2021).

\section{Research Methods}

The research depends on a fieldwork survey for heritage hotel guests in Cairo. The main objective is to explore the role of heritage hotels in increasing the number of tourists coming to Cairo. The survey includes the dimensions of tourists flow rates as discussed by (Onis, 2017): service quality, guest loyalty, service cost, technology use, market share, brand image and hotel location. Based on (Smith et al., 2013 \& Idilfitri, 
et al., 2015) the cultural attractions include monument, historical buildings, museums, handicraft, climate, shopping places and souvenirs. Cultural heritage helps heritage guests to enjoy the cultural diversity of the region, and bring in dialogue amongst different cultures (Franchi, 2020).

\subsection{Pilot Study}

Before carrying out the full study, a pilot study was carried out to assess the acceptability of the survey approach for the larger scale study.

\subsubsection{Basis for Determining Pilot Study Size}

According to (Viechtbauer et al., 2015), the numbers of respondents in the pilot study with a confidence level of $95 \%$ and a probability of $5 \%$ equaled 59 participants. Therefore, the pilot study was conducted on 59 guests in selected hotels through preplanned interviews to explore the relationship between heritage hotels and tourist flow rates.

\subsubsection{Reliability of Pilot Study}

Cronbach's coefficient alpha $(\alpha)$ was used to test the reliability of the pilot study's which came out as 0.939 (very reliable).

\subsubsection{Results of Pilot Study}

The pilot study results included that $93 \%$ of the respondents think that heritage destinations play a role in protecting the environment, help create vibrant communities and sustain local economies. $91 \%$ of the respondents thought that heritage hotels contribute to a better quality of life and cultural identity for the community. $89 \%$ of the respondents believed that heritage hotels have competitive advantages that utilize the resources effectively to improve guest satisfaction.

\subsection{Questionnaire population and Sample Characteristics}

To investigate the relationship between heritage hotels and tourist flow rates of Cairo's heritage hotels, the field study focused on hotel guests staying at five and four-star hotels in Cairo. The occupancy rate in most Cairo hotels ranged from 35\% to $43 \%$ in the period of January to March 2021 because of the COVID-19 pandemic and its precautionary measures. The estimated number of tourists in Cairo during that period was about 11500 tourists (Ministry of Tourism, 2020). The questionnaire sample size was calculated to be 372, using the following equation (Mekky, 2017):

$$
\begin{gathered}
\mathbf{n}=\frac{N \times[\theta(1-\theta)]}{N \times\left(\frac{\beta}{Z}\right)^{2}+\theta(1-\theta)} \\
\mathbf{n}=\frac{11500 \times[0.50(1-0.5 \phi]}{11500 \times\left(\frac{0.05}{1.96}\right)^{2}+0.50(1-0.50)}=372 .
\end{gathered}
$$

Where;

$\mathrm{n}=$ Sample size. 
$\theta=$ Percentage of phenomena, equal to 0.50 .

$\beta=$ A margin of error of 0.05 .

$\mathrm{N}=$ Population Size.

$\mathrm{Z}=$ The standard value at confidence level of $95 \%$, equal to 1.96 .

\subsection{Methods of Data Collection}

\subsubsection{Questionnaire Design}

The online questionnaire forms had four parts; Part one had the demographic data of the participant (gender, age, educational level, profession \& nationality). Part two had tested the characteristic of tourists' preferences (service quality, guest loyalty, service cost, technology use, market share, brand image \& hotel location). Part three had the cultural destination sites' elements (monument, historical buildings, museums, handicraft, climate, shopping places \& souvenirs). Part four questioned the heritage hotel components that guests would expect to have heritage features.

\subsubsection{Questionnaire Distribution}

A total number of 372 online questionnaires were sent to hotel guests in 12 hotels (31 forms per every hotel), 255 responses came back as valid, achieving a response rate $(68.5 \%)$.

Table 3

Hotels' Sample Profile

\begin{tabular}{|l|c|c|c|c|c|}
\hline $\begin{array}{c}\text { Hotel } \\
\text { Classification }\end{array}$ & $\begin{array}{c}\text { Total no. } \\
\text { of Hotels }\end{array}$ & $\begin{array}{c}\text { Selected } \\
\text { Hotels }\end{array}$ & $\begin{array}{c}\text { Distribute } \\
\text { d Forms }\end{array}$ & $\begin{array}{c}\text { Total } \\
\text { Responses } \\
(372)\end{array}$ & $\begin{array}{c}\text { Valid } \\
\text { Responses } \\
(\mathbf{2 5 5})\end{array}$ \\
\hline Five Star Hotels & 29 hotels & 7 hotels & 31 forms & $217(49)$ & 168 \\
\cline { 1 - 2 } \cline { 5 - 6 } Four Star Hotels & 21 hotels & 5 hotels & per hotel & $155(68)$ & 87 \\
\hline
\end{tabular}

Source: Egyptian Hotel Guide, 2020.

\subsubsection{Questionnaire Validity and Reliability}

Cronbach's alpha test was used to test the reliability of the study, the 22 items of the questionnaire had an Alpha Correlation Coefficient (ACC) of 0.9192 which is reliable. In addition, the questionnaire form was tested for content validity by ten hotel executives and five academic staff from the faculties of tourism and hotel management (face validity), their comments were included by adding, deleting and paraphrasing the forms' final design.

\subsection{Data Analysis}

\subsubsection{Analysis of Demographic Profile of Respondents}

Table 4

Descriptive Statistics for the Sample's Demographic Variables

1- Gender

\begin{tabular}{|c|c|c|}
\hline Gender & $N$ & $\%$ \\
\hline - Male & 112 & 43.9 \\
\hline - Female & 143 & 56.1 \\
\hline Total & 255 & 100 \\
\hline & & Continued \\
\hline
\end{tabular}


2- Age

\begin{tabular}{|c|c|c|}
\hline Age & $N$ & $\%$ \\
\hline - Under 24 years & 28 & 10.9 \\
\hline - From 25 - 44 years & 50 & 19.8 \\
\hline - From 45 - 64 years & 123 & 48.1 \\
\hline - Over 65 years & 54 & 21.2 \\
\hline Total & 255 & 100 \\
\hline
\end{tabular}

3- Educational Level

\begin{tabular}{|c|c|c|}
\hline Education Level & $N$ & $\%$ \\
\hline - High school & 27 & 10.5 \\
\hline - Bachelor's degree & 196 & 76.8 \\
\hline - Master's degree or above & 32 & 12.7 \\
\hline $\begin{array}{ll} & \text { Total } \\
\end{array}$ & 255 & 100 \\
\hline
\end{tabular}

4- Profession

\begin{tabular}{|c|c|c|}
\hline Profession & $N$ & $\%$ \\
\hline - Trainee & 30 & 11.7 \\
\hline - Employee & 34 & 13.4 \\
\hline - Others & 191 & 74.9 \\
\hline Total & 255 & 100 \\
\hline
\end{tabular}

5- Nationality

\begin{tabular}{|c|c|c|}
\hline Nationality & $N$ & $\%$ \\
\hline - Egyptian & 62 & 24.3 \\
\hline - Others & 193 & 75.7 \\
\hline Total & 255 & 100 \\
\hline
\end{tabular}

The total sample consisted of (255) hotel guests. (56.1\%) were females and $(43.9 \%)$ were males. Most of participants are between 45 to 64 years old $(48.1 \%)$ and $(21.2 \%)$ more than 65 years. Most of them had a university degree $(76.8 \%)$ and some of them have a postgraduate degree (Master's \& Doctorate) $(12.7 \%)$. More than half of the participants $(74.9 \%)$ were retirees and pensioners. $(75.7 \%)$ were foreigners from different nationalities such as: England, Italy, German, China \& Ukraine, and $(24.3 \%)$ were Egyptians.

\subsubsection{Analysis of Tourists' Preferences Attributes}

\section{Table 5}

Descriptive Statistics of Characteristics of Tourists' Preferences

\begin{tabular}{|l|c|c|c|c|c|c|}
\hline $\begin{array}{c}\text { Tourists' } \\
\text { Preferences }\end{array}$ & $\begin{array}{c}\text { Very } \\
\text { Dissatisfied }\end{array}$ & Dissatisfied & OK & Satisfied & $\begin{array}{c}\text { Very } \\
\text { Satisfied }\end{array}$ & Total \\
\hline - Service quality & 3 & 8 & 55 & 61 & 128 & 255 \\
\cline { 2 - 7 } & $1.2 \%$ & $3.1 \%$ & $21.6 \%$ & $23.9 \%$ & $50.2 \%$ & $100 \%$ \\
\hline - Guest loyalty & 9 & 19 & 113 & 78 & 36 & 255 \\
\cline { 2 - 7 } & $3.5 \%$ & $7.5 \%$ & $44.3 \%$ & $30.5 \%$ & $14.2 \%$ & $100 \%$ \\
\hline - Service cost & 5 & 6 & 28 & 91 & 125 & 255 \\
\hline
\end{tabular}




\begin{tabular}{|l|c|c|c|c|c|c|}
\hline & $1.9 \%$ & $2.3 \%$ & $11.0 \%$ & $35.7 \%$ & $49.1 \%$ & $100 \%$ \\
\hline - Technology use & 6 & 7 & 46 & 111 & 85 & 255 \\
\cline { 2 - 7 } & $2.4 \%$ & $2.7 \%$ & $18.1 \%$ & $43.5 \%$ & $33.3 \%$ & $100 \%$ \\
\hline \multirow{2}{*}{ - Market share } & 4 & 16 & 79 & 114 & 42 & 255 \\
\cline { 2 - 7 } & $1.6 \%$ & $6.3 \%$ & $30.9 \%$ & $44.7 \%$ & $16.5 \%$ & $100 \%$ \\
\hline \multirow{2}{*}{ - Brand Image } & 1 & 4 & 58 & 71 & 121 & 255 \\
\cline { 2 - 7 } & $0.4 \%$ & $1.6 \%$ & $22.7 \%$ & $27.8 \%$ & $47.5 \%$ & $100 \%$ \\
\hline \multirow{2}{*}{ - Hotel location } & 2 & 3 & 48 & 78 & 124 & 255 \\
\cline { 2 - 7 } & $0.8 \%$ & $1.2 \%$ & $18.8 \%$ & $30.6 \%$ & $48.6 \%$ & $100 \%$ \\
\hline
\end{tabular}

The survey results as presented in the table (5) show the level of satisfaction for each tourists' preferences attribute that was further detailed in terms of the demographic qualities of the survey population (gender, age \& educational level) as follows:

- Service quality (74.1\%): [59\% females \& 41\% males] - [41\% from 45-64 years, $22 \%$ from $25-44$ years, $19 \%$ over 65 years, $18 \%$ under 24 years] - in addition the higher education bracket of the population were more satisfied than the less educated $[79 \%$ bachelor's degree, $13 \%$ postgraduate degree and $8 \%$ high school certificate].

- Guest loyalty (44.3\%): [55\% females \& 45\% males] - [37\% over 65 years, $28 \%$ from 45-64 years, $18 \%$ from 25-44 years, 17\% under 24 years] - [78\% bachelor's degree, $14 \%$ postgraduate degree and $8 \%$ high school certificate].

- Service cost $(84.8 \%)$ : [64\% females \& 36\% males] -[39\% from 25-44 years, $21 \%$ from 45-64 years, 22\% under 24 years and18\% over 65 years] - [81\% bachelor's degree, $11 \%$ postgraduate degree and $8 \%$ high school certificate].

- Technology use (76.8\%): [66\% males \& 34\% females] - [36\% under 24 years, 18\% from $25-44$ years, $36 \%$ over 65 years and 31\% from $45-64$ years] - [77\% bachelor's degree, $15 \%$ postgraduate degree and $8 \%$ high school certificate].

- Market share (61.2\%): [68\% males \& 32\% females] - [41\% from 45-64 years, 28\% from 25-44 years, $18 \%$ over 65 years and $13 \%$ under 24 years] - [78\% bachelor's degree, $15 \%$ postgraduate degree and $7 \%$ high school certificate].

- Brand image (75.3\%): [59\% females \& 41\% males] - [33\% over 65 years, 30\% from 45-64 years, 21\% from 25-44 years and 16\% under 24 years] - [69\% bachelor's degree, $24 \%$ postgraduate degree and $7 \%$ high school certificate].

- Hotel location (79.2\%): [61\% females \& 39\% males] - [36\% over 65 years, 31\% from 45-64 years, $18 \%$ from 25-44 years, 15\% under 24 years] - [77\% bachelor's degree, $15 \%$ postgraduate degree and $8 \%$ high school certificate].

According to the previous analysis, the attributes of tourists' preferences for heritage hotels involve: service cost $(84.8 \%)$, hotel location $(79.2 \%)$, technology use $(76.8 \%)$, brand image $(75.3 \%)$, service quality $(74.1 \%)$, market share $(61.2 \%)$ and guest loyalty $(44.3 \%)$. 


\subsubsection{Analysis of Evaluation of Destination Sites \& Heritage Hotels}

\section{Table 6}

Descriptive Statistics of Destination Sites \& Heritage Hotels

\begin{tabular}{|c|c|c|c|c|c|c|}
\hline $\begin{array}{c}\text { Culture } \\
\text { Destination Site }\end{array}$ & $\begin{array}{c}\text { Very } \\
\text { Dissatisfied }\end{array}$ & Dissatisfied & $O K$ & Satisfied & $\begin{array}{c}\text { Very } \\
\text { Satisfied }\end{array}$ & Total \\
\hline \multirow[t]{2}{*}{ - Monuments } & 3 & 8 & 18 & 37 & 189 & 255 \\
\hline & $1.2 \%$ & $3.1 \%$ & $7.1 \%$ & $14.5 \%$ & $74.1 \%$ & $100 \%$ \\
\hline \multirow{2}{*}{$\begin{array}{l}\text { - Historical } \\
\text { buildings }\end{array}$} & 6 & 4 & 26 & 41 & 178 & 255 \\
\hline & $2.4 \%$ & $1.5 \%$ & $10.2 \%$ & $16.1 \%$ & $69.8 \%$ & $100 \%$ \\
\hline \multirow[t]{2}{*}{ - Museums } & 7 & 3 & 29 & 65 & 151 & 255 \\
\hline & $2.7 \%$ & $1.2 \%$ & $11.4 \%$ & $25.5 \%$ & $59.2 \%$ & $100 \%$ \\
\hline \multirow[t]{2}{*}{ - Handicraft } & 2 & 9 & 134 & 44 & 66 & 255 \\
\hline & $0.7 \%$ & $3.5 \%$ & $52.6 \%$ & $17.3 \%$ & $25.9 \%$ & $100 \%$ \\
\hline \multirow[t]{2}{*}{ - Climate } & 0 & 3 & 55 & 68 & 129 & 255 \\
\hline & $0.0 \%$ & $1.2 \%$ & $21.5 \%$ & $26.7 \%$ & $50.6 \%$ & $100 \%$ \\
\hline \multirow{2}{*}{$\begin{array}{l}\text { - Shopping } \\
\text { places }\end{array}$} & 13 & 19 & 98 & 58 & 67 & 255 \\
\hline & $5.1 \%$ & $7.5 \%$ & $38.4 \%$ & $22.7 \%$ & $26.3 \%$ & $100 \%$ \\
\hline \multirow[t]{2}{*}{ - Souvenirs } & 5 & 7 & 67 & 124 & 52 & 255 \\
\hline & $1.9 \%$ & $2.7 \%$ & $26.3 \%$ & $48.7 \%$ & $20.4 \%$ & $100 \%$ \\
\hline
\end{tabular}

The results explained in the table (6) shows the heritage destination site attributes that proved to satisfy the surveyed respondents (gender, age and educational level):

- Monuments (88.6\%): [59\% females \& 41\% males] - [32\% from $45-64$ years, 31\% over 65 years, $19 \%$ from $25-44$ years, $18 \%$ under 24 years] - [75\% bachelor's degree, $18 \%$ postgraduate degree and $7 \%$ high school certificate].

- Historical buildings (85.9\%): [61\% males \& 39\% females] - [33\% over 65 years, $31 \%$ from $45-64$ years, $21 \%$ from $25-44$ years, $15 \%$ under 24 years] - [77\% bachelor's degree, $14 \%$ postgraduate degree and $9 \%$ high school certificate].

- Museums (84.7\%): [57\% females \& 43\% males] - [34\% from 45-64 years, $29 \%$ over 65 years, $19 \%$ under 24 years, $18 \%$ from $25-44$ years] - [74\% bachelor's degree, $18 \%$ postgraduate degree and $8 \%$ high school certificate].

- Handicraft (43.2\%): [58\% males \& $42 \%$ females] - [37\% from $25-44$ years, $31 \%$ from 45-64 years, $19 \%$ over 65 years, $13 \%$ under 24 years] - [80\% bachelor's degree, $12 \%$ postgraduate degree and $8 \%$ high school certificate].

- Climate (77.3\%): [52\% males \& 48\% females] - [31\% over 65 years, $30 \%$ from 45-64 years, 20\% from 25-44 years, $19 \%$ under 24 years] - [76\% bachelor's degree, $15 \%$ postgraduate degree and $9 \%$ high school certificate].

- Shopping places (49\%): [68\% females \& 32\% males] - [31\% under 24 years, $29 \%$ from 25-44 years, $26 \%$ from 45-64 years, $14 \%$ over 65 years] - [76\% bachelor's degree, $16 \%$ postgraduate degree and $8 \%$ high school certificate].

- Souvenirs (69.1\%): [61\% females \& 39\% males] - [28\% from 45-64 years, 27\% from $25-44$, years, $23 \%$ under 24 years, $22 \%$ over 65 years] - [73\% bachelor's degree, $19 \%$ postgraduate degree and $8 \%$ high school certificate]. 
According to the previous analysis, the attributes of tourists selecting a heritage destination site include monuments and archeological sites (88.6\%), historical buildings $(85.9 \%)$, museums $(84.7 \%)$, work climate $(77.3 \%)$, souvenirs $(69.1 \%)$, shopping places (49\%) and handicraft (43.2\%).

\subsubsection{Analysis of Guest Characteristics for Heritage Sites}

The following table shows the respondents' behavior of selecting heritage hotels and heritage destinations:

Table 7

Number of Times Visiting the Heritage Hotels

\begin{tabular}{l|c|c|}
\hline \multicolumn{1}{|c|}{ Item } & $\mathbf{N = 2 5 5}$ & $\mathbf{\%}$ \\
\hline $\begin{array}{l}\text { 1- Have you ever been to a cultural sites and heritage hotels except this trip in the } \\
\text { past 3 years? }\end{array}$ & 216 & $84.7 \%$ \\
\hline - Yes & 39 & $15.3 \%$ \\
\hline - No & 37 & $17.1 \%$ \\
\hline If Yes, Please state the number of times did you travel to this place: \\
\hline - One time & 101 & $46.7 \%$ \\
\hline - Two times & 78 & $36.1 \%$ \\
\hline - More than three times
\end{tabular}

Most of the participants (84.7\%) visited the cultural sites and heritage hotels at least two times $(46.7+36.1=82.8 \%)$, which support a general trend of the research, which means that most of tourists like heritage hotels more than other standard hotels.

\section{Table 8}

Planning for the Trip in the Heritage Hotels

\begin{tabular}{|l|c|c|}
\hline \multicolumn{1}{|c|}{ Item } & N=255 & \% \\
\hline 2- How far did you begin planning the trip to heritage hotels? & \\
\hline - Less than 3 months & 89 & $34.9 \%$ \\
\hline - 3 to 6 months & 94 & $36.9 \%$ \\
\hline - 6 months to a year & 48 & $18.8 \%$ \\
\hline - More than a year & 24 & $9.40 \%$ \\
\hline
\end{tabular}

Most of the respondents (36.9\%) plan a trip to visit heritage hotels from 3 to 6 months, while others (34.9\%) take less than 3 months to plan a trip to visit this type of hotels. (18.8\%) of them plan a trip to heritage hotels from 6 months to a year, and $(9.4 \%)$ of them take more than a year to plan a trip to this type of hotels.

\section{Table 9}

Kinds of Heritage Assets

\begin{tabular}{|l|c|c|}
\hline \multicolumn{1}{|c|}{ Item } & N=255 & $\%$ \\
\hline 3- What kind of heritage assets do you tend to visit? & 69 & $27.1 \%$ \\
\hline - Monuments & 47 & $18.4 \%$ \\
\hline - Museums art collections & 115 & $45.1 \%$ \\
\hline - Historical hotels & 24 & $9.40 \%$ \\
\hline - Others,
\end{tabular}

Most of the participants (45.1\%) considered staying in heritage hotels an important component of their heritage accommodations, this type of hotels have always attracted travelers from different countries, while other participants prefer to visit 
monuments $(27.1 \%)$ and museum art collection (18.4\%) respectively, and $(9.4 \%)$ of them prefer to visit historic motor vehicles \& military equipment as a heritage assets.

\section{Table 10}

Describe the Visit to a Heritage Hotel

\begin{tabular}{|l|c|c|}
\hline \multicolumn{1}{|c|}{ Item } & N=255 & \% \\
\hline 4- How can you describe your visit to a heritage hotel? & 32 & $12.6 \%$ \\
\hline - Short visits & 223 & $87.4 \%$ \\
\hline - Long stays overnight
\end{tabular}

Most of the respondents $(87.4 \%)$ preferred a long vacation when planning to stay in heritage hotels, while a small percentage of them (12.6\%) preferred short day visits.

\section{Table 11}

Hotel Heritage Components

\begin{tabular}{|l|c|c|}
\hline \multicolumn{1}{|c|}{ Item } & $\boldsymbol{N}=\mathbf{2 5 5}$ & $\mathbf{\%}$ \\
\hline 5- In which parts of the hotel would you prefer to express the heritage components? \\
\hline - The whole hotel & 34 & $13.3 \%$ \\
\hline - Guest rooms & 44 & $17.3 \%$ \\
\hline - External building & 47 & $18.4 \%$ \\
\hline - Lobby & 35 & $13.7 \%$ \\
\hline - Hotel architecture design & 67 & $26.3 \%$ \\
\hline - Public areas & 28 & $11.0 \%$ \\
\hline
\end{tabular}

The impact of the overall heritage hotel architecture appeared to be more important to the guests $(26.3 \%)$ over other heritage hotel characteristics such as external building $(18.4 \%)$, the guest rooms $(17.3 \%)$, the hotel lobby $(13.7 \%)$, the whole hotel $(13.3 \%)$ and the public areas (11\%).

\section{Table 12}

Accompanying when Visiting Heritage Sites

\begin{tabular}{|l|c|c|}
\hline \multicolumn{1}{|c|}{ Item } & $\boldsymbol{N}=\mathbf{2 5 5}$ & \% \\
\hline 6- With whom have you visited the heritage site more frequently? \\
\hline - Alone & 39 & $15.3 \%$ \\
\hline - With friends & 105 & $41.2 \%$ \\
\hline - With family & 98 & $38.4 \%$ \\
\hline - Others, & 13 & $5.10 \%$ \\
\hline
\end{tabular}

Most of the respondents prefer to visit the heritage sites with their friends $(41.2 \%)$ and families $(38.4 \%)$ respectively, total of $79.6 \%$, while some of them indicated that they could go alone (15.3\%). This supports a general design guideline for having more double rooms than single rooms in heritage hotels.

\section{Table 13}

Type of Sources of Information on Heritage Sites

\begin{tabular}{|l|c|c|}
\hline \multicolumn{1}{|c|}{ Item } & $\boldsymbol{N}=\mathbf{2 5 5}$ & $\mathbf{\%}$ \\
\hline 7- What type of sources of information about the heritage site? & \multicolumn{1}{|l|}{} \\
\hline - Newspaper & 18 & $7.00 \%$ \\
\hline - Internet & 199 & $78.1 \%$ \\
\hline - Television & 26 & $10.2 \%$ \\
\hline - Others, & 12 & $4.70 \%$ \\
\hline
\end{tabular}


Most of the participants used Web sites as preferred sources of information on heritage sites $(78.1 \%)$, while $(10.2 \%)$ only relied on TV channels, and (7\%) on newspapers as a source of information on heritage hotels.

\section{Table 14}

Positive Effects of Promoting Heritage Sites

\begin{tabular}{|c|c|c|}
\hline Item & $N=255$ & $\%$ \\
\hline \multicolumn{3}{|c|}{ 8- What are the positive effects of promoting heritage sites? } \\
\hline - Promote community pride & 64 & $25.1 \%$ \\
\hline - Create jobs & 87 & $34.1 \%$ \\
\hline - Protect natural \& cultural resources & 93 & $36.5 \%$ \\
\hline - Others, & 11 & $4.30 \%$ \\
\hline
\end{tabular}

Most of the respondents stated that the positive aspects of heritage sites is to protect natural and cultural resources (36.5\%), and to create several jobs (34.1\%), While some respondents indicated that heritage hotels develop a sense of pride to the host community $(25.1 \%)$. Some of them $(11 \%)$ indicated that the negative effects might include its impact on the local economy that may be unstable and thus increase the costs of living for the locals, over exploitation of resources, and excessive landscape impact by building out of control.

\subsubsection{Research Hypothesis Testing}

Through the statistical analysis of the data received from the targeted sample, it was found that there is a direct correlation between vesting heritage hotels and the increase in number of tourists in Cairo, this is illustrated by the following table, which shows the relationship between the two variables:

\section{Table 15}

The Relation between the Two Variables

\begin{tabular}{|c|c|c|c|}
\hline Statistical Tool & $\begin{array}{c}\text { Contingency } \\
\text { Coefficient }\end{array}$ & Chi Square Test & Sig. \\
\hline Questionnaire Form & 0.759 & 24.85 & 0.05 \\
\hline
\end{tabular}

Through the statistical analysis of the table 15 using the "Contingency Coefficient", it appears that there is a strong, positive, statistically significant relationship between the heritage hotels and tourist flow rates, where the calculated value of the contingency coefficient equal to 0.759 and by converting it to the value of the chisquare to determine the level of significance required, it was found that the value of the contingency coefficient is statistically significant at the level of significance 0.05 .

A Pearson correlation analysis was conducted to examine whether there is a relationship between heritage hotels and increasing the number of tourists in Cairo, the following table shows that: 
Table 16

Pearson Correlation between the Variables

\begin{tabular}{|l|l|c|c|}
\hline \multicolumn{2}{|c|}{ Variables } & $\begin{array}{c}\text { Heritage } \\
\text { Hotels }\end{array}$ & $\begin{array}{c}\text { Number of } \\
\text { Tourists }\end{array}$ \\
\hline Heritage Hotels & Pearson Correlation & 1 & $.170^{*}$ \\
& Sig. (2-tailed) & & .025 \\
& $\mathrm{~N}$ & 255 & 255 \\
\hline Number of Tourists & Pearson Correlation & $.170^{*}$ & 1 \\
& Sig. (2-tailed) & .025 & 255 \\
\hline & $\mathrm{N}$ & 255 & 255 \\
\hline
\end{tabular}

* Correlation is significant at the 0.05 level (2-tailed).

The results revealed a significant and positive relationship between the two variables; Heritage hotels were associated with increasing the number of tourists in Cairo, Thus, it was possible to prove the validity of the hypothesis of the study, which is:

There is a significant relationship between heritage hotels and increasing the number of tourists in Cairo, Egypt.

\section{Research Results}

This study aimed to examine the relationship between heritage hotels and increasing the number of tourists in Cairo, which hosts a variety of historically significant districts and monuments, ranging from the ruins of al-Fustat, the Fatimid nucleus of Medieval Cairo, the citadel and surrounding Mamluk palaces, to its urban domestic architecture, mausoleums, bazaars, its Nilometre and other inventions related to human use and mastery of the River Nile (Unesco, 2020). The findings had highlighted some of the key principles of heritage hotels that indicated that most of participants $(45.1 \%)$ were preferred the historical hotels as a favorite pattern of heritage assets due to the variety of reasons: memorable trip, diversifies the tourism experience, reinforces identity, increases the learning capacity and strengthens local economies. Most of them believe that the architecture design of the hotel $(26.3 \%)$ and external building (18.4\%) expresses the heritage components. Most of them use the internet sites as a preferred source of information on heritage sites (78.1\%), and they can see positive effect of promoting the cultural destination sites in preserving the region's natural \& cultural resources (36.5\%), and creating jobs for local community $(34.1 \%)$. In addition, most of them are very satisfied about the characteristics of tourists' preferences, which involve service quality (50.2\%), service cost $(49.1 \%)$, hotel location $(48.6 \%)$, and brand image $(47.5 \%)$. Most of participants are very satisfied about the features of cultural sites, which include monuments $(74.1 \%)$, historical buildings (69.8\%), museums (59.2\%), and climate (50.6\%).

\section{Recommendations}

The following recommendations were concluded:

- Tourists' preferences attributes are linked to heritage hotels in Cairo city, and this type of hotels attract special types of tourists with higher spending and education characteristics who tend to stay longer which might positively impact the hospitality sector. 
- Heritage hotels need to have clear heritage features in their overall design and exterior to match the anticipated image of the tourists. Adaptive re-use of existing heritage buildings would make good heritage hotels when sensitively restored through to preserve their heritage value.

- Creating heritage tours within Historical Cairo need to respect the heritage cycle and allow time to develop good understanding, value the assets, attract care by the proper entities in order to deserve the tourists' enjoyment. The heritage cycle deals with creating demand out of the already plentiful supply of monuments and heritage attractions within the world heritage site.

- Adaptive re-use of heritage buildings within the existing fabric of the historical city serves both the conservation objectives of the world heritage property while allowing tourists to experience the authenticity of the historical setting. Consequently, saving the old buildings would allow investment opportunities of the local investors and better incomes for the local entrepreneurs.

- Tour operator's involvement in creating tourism routes within Historical Cairo is essential for an inclusive heritage development that provides accommodation in heritage hotels and encourages the development of authentic local crafts.

- Heritage tourism to Historical Cairo needs creative marketing strategies that create "Local Brands" and network with similar regional and global electronic platforms about heritage hotels, heritage attractions and heritage festivities.

- It is necessary to develop the labor skills and train the local manpower to work for local heritage hotels to improve the community's acceptance of incoming tourists into their physical settings.

- Heritage tourism promotions need to focus on the tourists' preferences that the research found out to be valued by the tourists such as heritage flavored accommodations, authentic local crafts shopping, integrated tourism experiences and good amenities.

- Part of heritage tourism promotions need to develop the demand side by encouraging international and regional movies to use Historical Cairo heritage attractions for their plateau settings and to encourage visual documentaries to be filmed within the area.

- Heritage hotels within existing heritage buildings need to have their original history polished and well-presented to give tourists a glimpse of their deep cultural competitive advantages.

\section{Limitations and Further Research}

The research focused on studying the impact of heritage hotels on increasing tourist flow rates in Cairo's five and four-star hotels, which witnessed different cultures and civilizations through ages and became an open museum that includes Pharaonic, Greek, Roman, Coptic and Islamic monuments. The study was targeted the employees and high management staff of the selected hotels. More research is needed to study the economic impact of the COVID-19 on the influx of tourists to heritage hotels in Egypt, and to analyze the economic effects of heritage hotel tourists on Egyptian tourist destinations. 


\section{References}

Attiany, M., (2014). Competitive Advantage through Benchmarking: Field Study of Industrial Companies Listed in Amman Stock Exchange, Journal of Business Studies Quarterly, 5(4), pp. 41-51.

Brida, J., Meleddu, M. and Paulina, M., (2013). The Economic Impacts of Cultural Tourism. In The Routledge Handbook of Cultural Tourism, New York: Routledge.

CAPMS, (2021). Tourism in Egypt, The Central Agency for Public Mobilization and Statistics, Different Publications.

Cerisola, S., (2019). A New Perspective on the Cultural Heritage-Development Nexus: The Role of Creativity, Journal of Cultural Economics, 43 (1), pp. 21-56, Available at: https://ideas.repec.org/a/kap/jculte/v43y2019ild10.1007_s10824-018-9328-2.html, Last Accessed on 19 January 2021

Chan, K., (2021). Historical Hotels: What's Old Is New Again, Available at: https://pinnacleadvisory.com/press-room/historic-hotels-whats-old-is-new-again-presented-by-katherinechan/, Last Accessed on 10 January 2021.

Childs, C., (2018). How Culture and Heritage Tourism Boosts More Than A Visitor Economy, Available at: https://www.mytravelresearch.com/culture-and-heritage-tourismboosts-visitor-economy, Last Accessed on 23 November 2020.

Corporate Finance Institute, (2021). Constructing a Competitive Advantage, CFI Publications, Available at:

https://corporatefinanceinstitute.com/resources/knowledge/strategy/competitiveadvantage/, Last Accessed on 18 January 2021.

DMG Consulting Services, (2015). Impacts of Heritage Hotels in Country- Focus in Rural Area, Available at:

http://tourism.gov.in/sites/default/files/Other/HERITAGE\%20HOTEL.pdf, Last Accessed on 12 March 2021.

Egyptian Hotel Association, (2020). The Egyptian Hotel Guide, pp. 170-191.

Euro-monitor International, (2021). Tourism Flows in Egypt, Available at: https://www.euromonitor.com/tourism-flows-in-egypt/report, Last Accessed on 17 October 2021.

Farag, M., (2021). Tourism in Egypt: 2021, the Year of the Corona Pandemic, Available at: https://www.skynewsarabia.com/business/1412624-\%D8\%A7\%D9, Last Accessed on 21 October 2021.

Franchi, H., (2020). What is Cultural Heritage?, Available at: https://www.khanacademy.org/humanities/special-topics-art-history/arches-at-riskcultural-heritage-education-series/arches-beginners-guide/a/what-is-cultural-heritage, Last Accessed on 15 March 2021.

Gibson, J., (2015). Today's Word: Heritage Tourism, Available at: https://savingplaces.org/stories/preservation-glossary-todays-word-heritage-tourism\#.X Ao9 w 4 szals, Last Accessed on 13 November 2020.

Harris, L., (2010). Who is the Heritage Tourism Traveler?, Available at: https://www.georgia.org/sites/default/files/wp-uploads/2013/09/GA-Heritage-TourismHandbook.pdf, Last Accessed on 19 November 2020.

Haynes, C., (2018). The Benefits and Disadvantages of Heritage Tourism in the Conservation and Management Of Caribbean Heritage, Available at: https://www.caribheritage.org/blog/benefits-and-disadvantages-heritage-tourismconservation-and-management-caribbean-heritage, Last Accessed on 11 November 2020.

Helly, D., (2014). Culture in Eu's External Relations - Egypt Country Report, Available at: http://ec.europa.eu/assets/eac/culture/policy/international- 
cooperation/documents/country-reports/egypt_en.pdf, Last Accessed on 11 December 2020.

Historic Hotels of Egypt - HHE, (2021). Retrieved from: https://historichotels.com.eg/en/our-hotels.html, Last Accessed on 22 January 2021.

Idilfitri, S., Rodzi, N., Mohamad, N. and Sulaiman, S., (2015). Public Perception of the Cultural Perspective towards Sustainable Development, Procedia - Social and Behavioral Sciences, p.p. 168 - 191, Available at: www.sciencedirect.com, Last Accessed on 14 March 2021.

Jackson, M., (2020). Heritage Travel: What it is \& How it Can Benefit you, Available at: https://www.goabroad.com/articles/heritage-travel, Last Accessed on 29 December 2020.

Kumar, A., (2017). Cultural and Heritage Tourism: A Tool for Sustainable Development, Journal of Commerce and Management Perspective, Vol. 6, No. 6, pp. 56-59.

Lee, W. and Chhabra, D., (2015). Heritage Hotels and Historic Lodging: Perspectives on Experiential Marketing and Sustainable Culture, Journal of Heritage Tourism, Vol. 10, No. 2, pp. 103-110.

Mekky, M., (2018). The Impact of Transformational Leadership on Team Effectiveness : The Mediating Role of Interaction Justice -An Empirical Study-, Unpublished DBA Thesis, Faculty of Commerce, Business Administration Department, Cairo University.

Onis, A., (2017). The Role of Strategic Intelligence in Achieving Competitive Advantage in the Organization - Case Study of Algeria Telecom, Unpublished Master Thesis, Faculty of Economic and Business Sciences, University of Muhammad Khaider, Algeria.

Ouf, A., (2020). Urban Regeneration of Historic Cairo (URHC), Ministry of Archeology and Tourism in Egypt, Funded-research.

Oxford Business Group, (2021). What Reforms are Supporting Egypt's Tourism Industry?, Available at:

https://oxfordbusinessgroup.com/overview/steady-progress-comprehensive-reform-andinvestment-infrastructure-support-long-term-growth, Last Accessed on 10 March 2021.

Pangestu, M., (2021). Tourism in the Post-COVID World: Three Steps to Build Better Forward, International Reports of World Bank.

Sameh, Y., (2019). Rediscovering Egypt's Historic Hotels, Available at: https://see.news/rediscovering-egypts-historic-hotels/, Last Accessed on 11 December 2020.

Smith, M. and Richards, G., (2013). The Routledge Handbook of Cultural Tourism, Routledge Press.

State Information Service, (2021). The Achievements of the Tourism Sector during the Year 2020, SIS Publications.

Stinson, S., (2010). The Importance of Heritage Tourism, Available at: https://www.blackmeetingsandtourism.com/Publications/Black-Meetings-Tourism/2010/ December-2009-January-2010/The-Importance-of-Heritage-Tourism.aspx/, Last Accessed on 20 January 2021.

The Egyptian Center for Economic Studies, (2021). Follow-up on the Effects of Covid-19 on the Egyptian Economy, Tourism Sector, - ECES Press, Issue no. 25, pp.1-21.

The Holding Company for Tourism and Hotels, (2021). List of Heritage Hotels in Egypt, Retrieved from:

https://www.hotac-eg.com, Last Accessed 20 October 2021.

Thurley, S., (2005). Into the Future-Our Strategy for 2005-2010, In: Conservation Bulletin [English Heritage], (49).

Tourism Development Authority, (2020). Hotels Annual Report, - Publications of Ministry of Egyptian Tourism. 
URHC, (2020). Urban Regeneration for Historic Cairo, Tourism Study, Vol. 1, p. 24.

Viechtbauer, W., Smits, L., Kotz, D., Bude, L., Spigt, M., Serroyen, J. and Crutzen, R., (2015). A Simple Formula for the Calculation of Sample Size in Pilot Studies, Journal of

Clinical Epidemiology, Vol. 68, pp. 1375-1379.

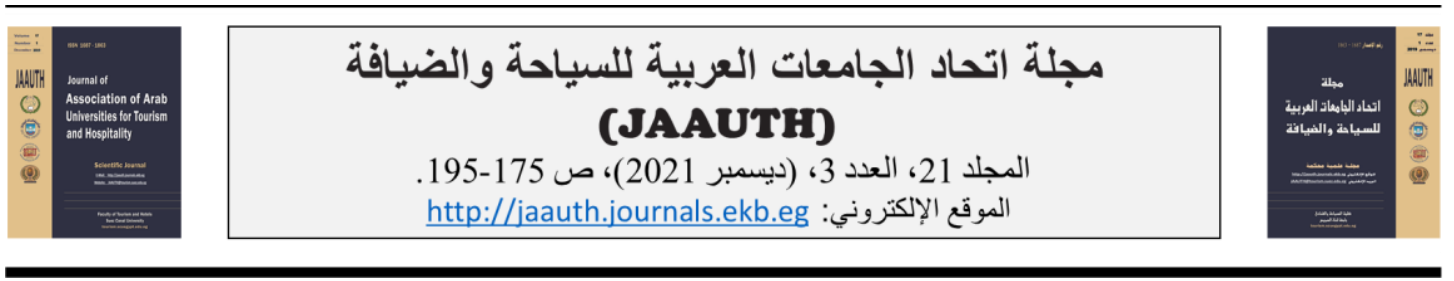

دور الفنادق التراثية فى زيادة معدلات التدفق السياحى بمدينة القاهرة - مصر

$$
\text { هانى صلاح صادق }
$$

المعهد العالى للدراسات النوعية بمصر الجديدة

معلومـات المقالة الكلمات المفتاحية

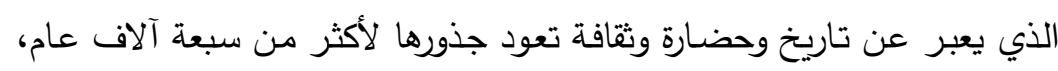

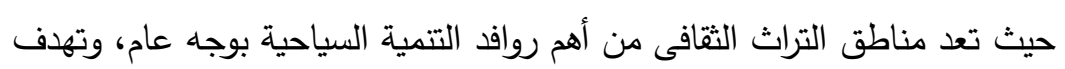

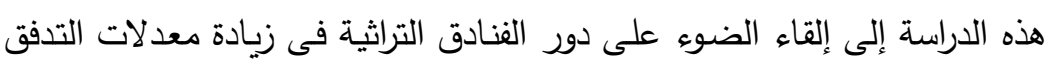
الفنـادق التراثيـة؛ التـدفق

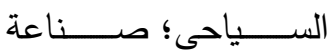

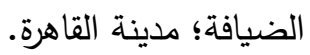
السياحى بمدينة القاهرة، حيث تضيف هذه النوعية من منشآت الإقامـة الفندقية بعداً جديداً يضـاف إلى جاذبية القاهرة التاريخية يتمثل فى الاهتمام بقيمة التراث

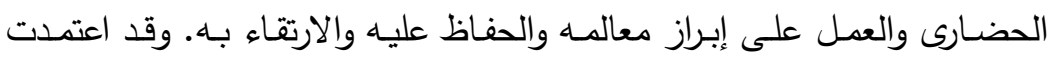

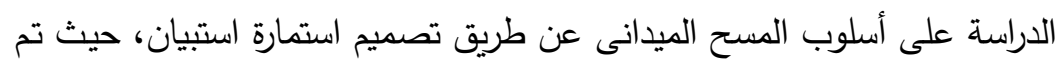
إرسال عدد 372 استبيانًا عبر الإنترنت إلى المبحوثين فى 12 فندقاً (31 استبانة

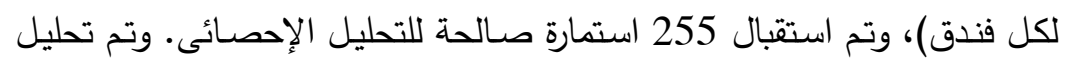

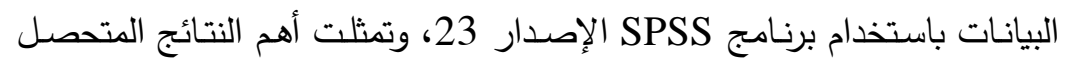
عليها فى أن هناك علاقة ارتباط ايجابية بين الفنادق التراثية في مدينة القاهرة

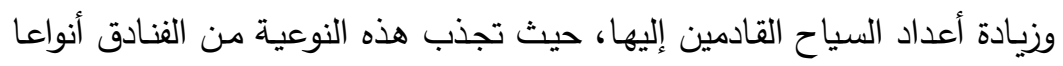

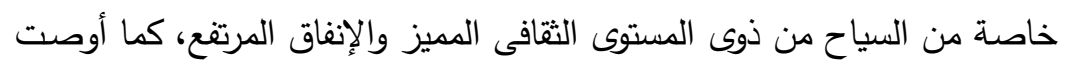

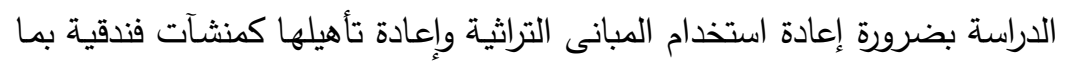

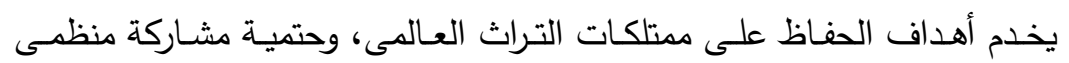
الرحلات السياحية فى إنشاء مسارات سياحية داخل القاهرة التاريخية فضـلا عن وهن أهمية وجود إدارة فعالة فى مناطق التراث الثقافى للارتقاء بهذه المناطق والحفاظ

\section{(JAAUTH)}

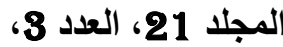

(ديسمبر (2021)

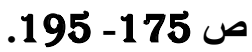

$$
\text { على محتواها العمرانى والتاريخى. }
$$

